\begin{tabular}{|c|c|}
\hline \multirow{3}{*}{ 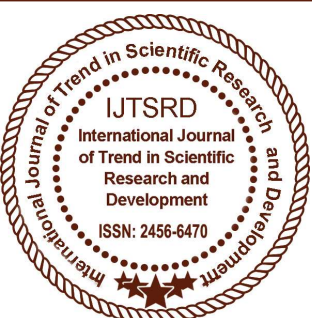 } & $\begin{array}{l}\text { International Journal of Trend in Scientific } \\
\text { Research and Development (IJTSRD) }\end{array}$ \\
\hline & Access Journal \\
\hline & ISSN No: $2456-6470$ | www.ijtsrd.com | Volume - 2 | Issue -4 \\
\hline
\end{tabular}

\title{
Combined Larvicidal and Pupicidal Action of Coriandrum sativum, Piper nigrum and Synthetic Insecticide Cypermethrin Against the Dengue Fever Mosquito, Aedes Aegypti L.
}

\author{
Dr. A. Noortheen ${ }^{1}$, B. Govindarajan ${ }^{1}$, Brabavathi $\mathbf{C}^{2}$ \\ ${ }^{1} \mathrm{PG}$ and Research Department of Zoology, V.H.N.S.N. College (Autonomous), \\ ${ }^{1}$ Virudhunagar, Tamil Nadu, India \\ ${ }^{2}$ Government Higher Secondary School, Perambalur, Tamil Nadu, India
}

\begin{abstract}
After the adoption of green revolution, India has The combined action of cypermethrin and methanolic extracts of Coriandrum sativum, Piper nigrum were observed for their larvicidal and pupicidal activites against Aedes aegypti. When analyzed individually, Cypermethrin were found to be most effectual against the first instar larvae of Aedes aegypti, followed by methanolic extracts of Piper nigrum, Coriandrum sativum being least effective. The $\mathrm{LC}_{50}$ values obtained with Cypermethrin and methanolic extracts of Piper nigrum, Coriandrum sativum against the first instar larvae were $0.61,0.71$ and $0.86 \%$, respectively and the $\mathrm{LC}_{90}$ values were $1.32,2.73$ and $3.71 \%$ respectively. The combination of Cypermethrin and Coriandrum sativum was studied at mixed with Cypermethrin 0.5\% and Coriandrum sativum 0.5, 1.0, 1.5, 2.0 and 2.5. Similar mixtures were also used for the combination of Cypermethrin and Piper nigrum. The Cypermethrin and Coriandrum sativum seed extract combination acted antagonistically. The combination of Cypermethrin and Piper nigrum seed extract acted synergistically against the target organisms at a first instar larvae, which showed the best results of: $\mathrm{LC}_{50} 0.58$ and $\mathrm{LC}_{90} 2.40 \%$ at 24 hours, respectively. The present study will be helpful in developing in a commercial formulation for effective vector management.
\end{abstract}

Keywords: Cypermethrin, Coriandrum sativum, Piper nigrum, Aedes aegypti, larvicide, pupicide and synergism

\section{INTRODUCTION}

Mosquitoes are major public health pests throughout the World. Among the 3492 species of mosquitoes recorded Worldwide, more than a hundred species are capable of transmitting various diseases to humans and $J$ other vertebrates (Rueda, 2008). Many devastating diseases such as malaria, West Nile virus (WN), dengue, filariasis, yellow fever, Japanese encephalitis and chikungunya are transmitted to humans by vector mosquitoes. Also mosquito bite causes considerable pain and leads to loss of sleep. Mosquito attack on frame animals can cause loss of body weight and decreased milk production (Nour et al., 2009). The Aedes aegypti mosquito is the primary vector of dengue. The Aedes aegypti mosquito lives in urban habitats and breeds mostly in man-made containers. Unlike other mosquitoes Aedes aegypti is a daytime feeder; its peak biting periods are early in the morning and in the evening before dusk. Female Aedes aegypti bites multiple people during each feeding period. As estimated 500000 people with severe dengue require hospitalization each year, a large proportion of whom are children. About $2.5 \%$ of those affected die. Dengue has become the most important mosquito-borne viral disease affecting humans (WHO, 2009). Dengue fever is a severe, flulike illness that affects infants, young children and adults, but seldom causes death. Dengue should be suspected when a high fever (40c-/104F) is accompanied by two of the following symptoms; severe headache, pain behind the eyes, muscle and joint pains, nausea, vomiting, swollen glands or rash. 
Insect pests have been controlled with synthetic insecticide over 50 years but problems of pesticide resistance and negative effects on non-target organisms, including human and environment have been reported (FAO, 1992). Botanical insecticides are considered as alternatives to the synthetic chemicals for being biodegradable, pest specific, non- hazardous to human health and environment and leaving no toxic residue in nature (Periera and Wohlgemuth, 1982).

Coriandrum sativum coriander (Family: Apiaceae). It is a herb that is often used as a side dish in Iranian cooking is a soft, hairless plant growing upto $50 \mathrm{~cm}$ in height and is native to Southwestern Asia and North Africa. All parts of the plant are edible, but the fresh leaves and the dried seeds are the most eaten parts of the plant (Burdock and Carabin, 2009). These seeds used to treat indigestion, aninexia and stomachache. Coriander seeds are ground into a paste for application to skin and mouth ulcers. Before the invasion of toothpaste, coriander seeds were chewed as a breath sweetener. Coriander is used in several ayurvedic remedies.

Piper nigrum (Family: Piperaceae) contains approximately 2000 species, which are widely grown and commonly used in tropical regions as medicines, spile and condiments in regional cuisine (Numba, 1993). Pepper plants have also been prescribed for pest control as they contain potentially insecticidal compounds (Su and Horvat, 1981).

Cypermethrin belongs to a class of insecticides known as synthetic pyrethroids. Cypermethrin is commonly used as a crack and crevice or spot treatment for residual and contact control of spiders, ants, carpenter ants, scorpions, German cockroaches, ladybugs, carpenter bees, and yellow jackets. In laboratory tests, cypermethrin was highly toxic to mosquito larvae and pupae. It was more toxic at low temperatures after a 24 hours exposure. No significant mortality of caged stickleback fish occurred in these pools (Helson and Surgeoner, 1986).

Synergistic activity between synthetic pesticides and botanicals is powerful and effective tool for the development of an efficient, more eco-friendly and less hazardous insect pest control strategy (Bernard and Philogne, 1993). The application of synergists has been preferred as a strategy to enhance the ecofriendliness and cost effectiveness of an insecticide by reducing the quantity needed to kill the target population and lengthen the residual activity. The role of synergists in resistance management is an accepted alternative for resistance management.

The importance of propel selection of plant extracts as synergists in mixed formulation with different synthetic insecticides is being increasely recognized in mosquito management. The mixture may provide less toxicity, prevent the development of resistance, have economic benefits and could be more effective than individual components of the mixture.

In the view of the above fact, an attempt has been made to evaluate the individual and combined effect of Coriandrum sativum, Piper nigrum and synthetic insecticide Cypermethrin against the lavicidal and pupicidal activity of the dengue vector, Aedes aegypti.

\section{METHODOLOGY}

The plants material of Coriandrum sativum (Family: Apiaceae), Piper nigrum (Family: Piperaceae) seeds were collected from Namakkal market, Tamil Nadu, India. The seeds of Coriandrum sativum and Piper nigrum were dried in shade under normal environmentalc condition and powdered by on electrical blender to coarse powder and stored in opaque screw tight jars until use. The dried Coriandrum sativum and Piper nigrum seeds powder $(30 \mathrm{~g})$ was extracted in Soxhlet apparatus with $300 \mathrm{ml}$ of $95 \%$ methonal at controlled temperature (Vogel, 1978). The collected extract was concentrated under reduced pressure $\left(<45^{\circ} \mathrm{C}\right)$ using a vacuum pump for complete removal of the solvent. Pure organic part of the sample thus prepared was stored at $4-5^{\circ} \mathrm{C}$ until used. $30 \mathrm{~g}$ of the plant residue was dissolved in 300 $\mathrm{ml}$ of methanol considered as 1\% stock solution. Each different concentration was prepared from stock solution.

Cypermethrin $(10 \% \mathrm{EC})$ or megathrin were obtained from the Agroform Namakkal District and diluted in dechlorinated tap water to obtain a concentration of $1 \%$ stock for cypermethirn. Different test concentrations ranging from 0.25 to $1.25 \%$ were prepared by diluting these stock solutions.

Keeping the cypermethrin as standard solution $(0.5 \%)$, the stock was mixed with the different percentage of the phytoextract Coriandrum sativum such as $0.5,1.0,1.5,2.0$ and 2.5 and Piper nigrum such as $0.5,1.0,1.5,2.0$ and 2.5 . 
The egg rafts of Aedes aegypti were collected from local in and around Namakkal District rain water bodies, water stored container with help of ' $\mathrm{O}$ ' type brush for the laboratory bioassay. These eggs were brought to the laboratory and were transformed to $18 \times 13 \times 4 \mathrm{~cm}$ size enamel trays containing $500 \mathrm{ml}$ of water and keep for larval hatching. The mosquito larval culture was maintained our laboratory at $27 \pm$ $2^{\circ} \mathrm{C}, 75-80 \%$ relative humidity under a period of $11 \pm 0.5 \mathrm{hrs}$ in the cycles. The mosquito larvae were feed with dog biscuits and yeast at 3:1 ratio. The feeding was continued till the larvae are transformed into the pupal stage. The pupae were collected from the culture trays and were transformed to conical flasks containing $500 \mathrm{ml}$ of water with help of sucker.

$\mathrm{LC}_{50}$ (lethal concentration $50 \%$ ) is the concentration of any toxic substance reducing by mortality the number of tested individuals to $50 \%$ in a prefixed time (Ravera, 1986). According to (Rand and Petrocelli, 1985) the $\mathrm{LC}_{50}$ (median lethal concentration) is estimated to produce mortality in $50 \%$ of a test solution over a specific period of time.

Preliminary tests were carried out to find the toxicityof the median lethal to tolerance limit of Aedes aegypti larvae to (Coriandrum sativum, Piper nigrum) seeds and synthetic insecticide for 24 hours. For determining $\mathrm{LC}_{50}$ concentration separate glass beaker of $100 \mathrm{ml}$ of water/capacity were taken. Then different concentration of two plants seeds extract and synthetic insecticide were added to different glass beakers. Then 10 Aedes aegypti was introduced in to each glass beaker, a control beaker with 10 larvae were also maintained. The mortality/ survical of larvae in the treatment glass beaker were recorded after 24 hours. The concentration at which $50 \%$ mortality of larval occurred after 24 hours was taken as the median lethal concentration $\left(\mathrm{LC}_{50}\right)$ for 24 hours. The $\mathrm{LC}_{50}$ concentration for 24 hours was calculated by the profit analysis method of (Finney, 1971).

A laboratory colony of Aedes aegypti larvae were used for the larvicidal toxicity. 25 numbers of first, second, third and fourth instar larvae were kept in 300 $\mathrm{ml}$ of plastic cup containing $249 \mathrm{ml}$ of dechlorinated water and $1 \mathrm{ml}$ of desired concentration of plants extracts of (Coriandrum sativum, Piper nigrum) seeds and synthetic insecticide were added. Larval food was given for the test larvae (WHO, 1996). At each tested concentration 1 to 5 trials were made and each trial consisted of five replicates. The control was setup by $250 \mathrm{ml}$ of dechlorinated water without plant extract and synthetic insecticide. In the larval toxicity, the larvae exposed to dechlorinated water without plant extract and synthetic insecticide served as control. Mortality was corrected by using Abbott's formula (Abbott, 1925).

Observed mortality in treatment Observed mortality in control

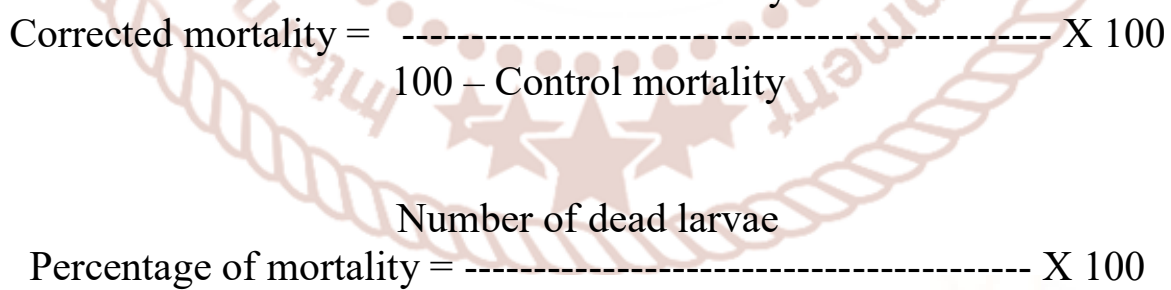

Number of larvae tested

The values of $\mathrm{LC}_{50}, \mathrm{LC}_{90}$ and their $95 \%$ confidence limit of upper confidence limit (UCL) and lower confidence limit (LCL) and Chi-square values were calculated by using profit analysis (Finney, 1971). The level of significance by Duncan's Multiple Range Test (Duncan, 1963).

A laboratory colony of Aedes aegypti were used for pupicidal toxicity test and 25 number of freshly emerged pupae were kept in $300 \mathrm{ml}$ plastic cup containing $249 \mathrm{ml}$ of dechlorinated water and $1 \mathrm{ml}$ of desired concentration of plants extracts of (Coriandrum sativum, Piper nigrum) seeds and synthetic insecticide were added. At each tested concentration 1 to 5 trials were made and each trial consisted of five replicates (WHO, 1996). The control was setup by $250 \mathrm{ml}$ of dechlorinated water without plant extract and synthetic insecticide. In the pupal toxicity, the pupae exposed to dechlorinated water without plant extract and synthetic insecticide served as control. Mortality was corrected by using Abbott's formula (Abbott, 1925). 


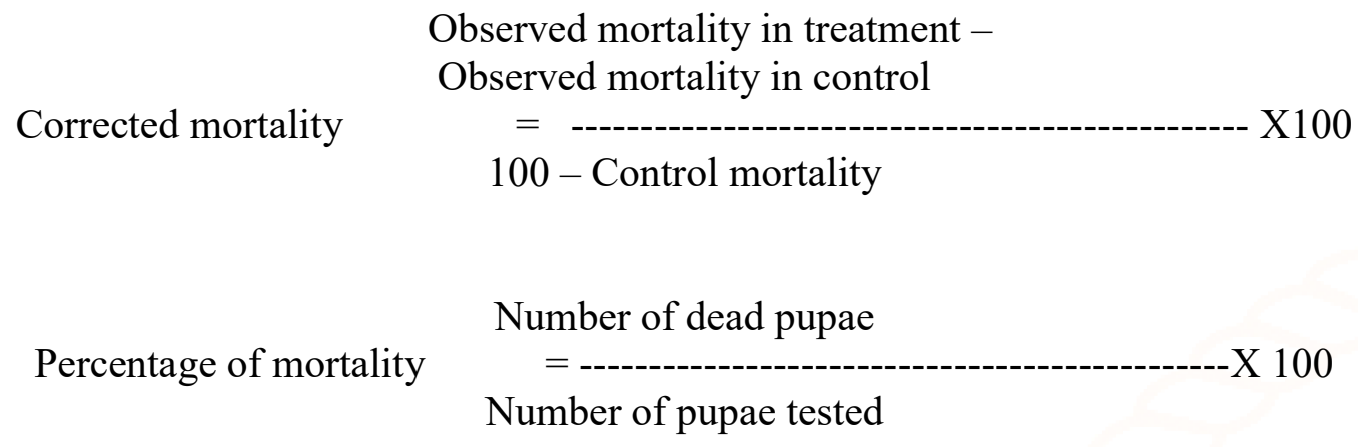

The values of $\mathrm{LC}_{50}, \mathrm{LC}_{90}$ and their $95 \%$ of confidence limit of upper confident limit (UCL) and lower confidence limit (LCL) and Chi-square values were calculated by using profit analysis (Finney, 1971). The level of significance by Duncan's Multiple Range Test (Duncan, 1963).

The methanolic extracts of Coriandrum sativum and Piper nigrum seed extract was tested for larvicidal and pupicidal efficacy of with and without insecticide (Cypermethrin). A control was setup by $250 \mathrm{ml}$ dechlorinated water. The synergistic factor was calculated from $\mathrm{LC}_{50}$ value of plant extract with insecticide. The synergistic (SF) is greater than one is considered to be synergism of SF value is less than one is considered to be antagonism.

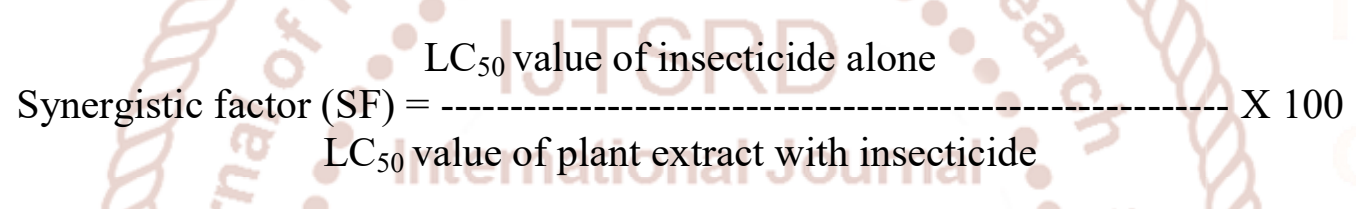

The tests with more than $20 \%$ mortality in control and pupae formed were discarded and repeated again. If the control mortality ranged between $5-20 \%$ it was corrected using Abbott's formula (Abbott, 1925).

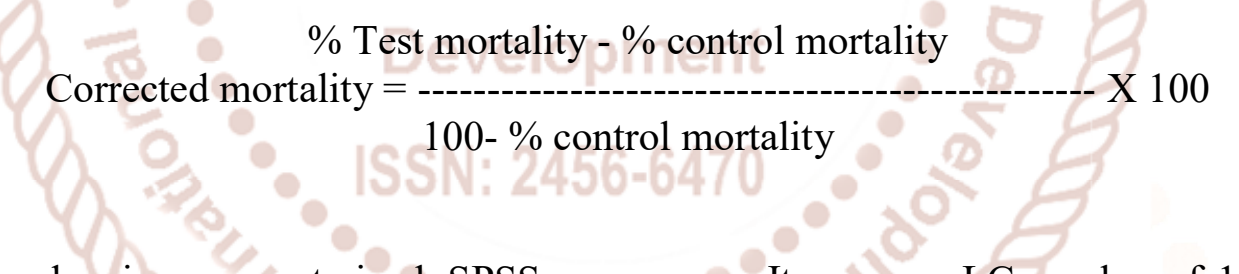

The data were analysed using computerized SPSS programme. The $\mathrm{LC}_{50}$ and $\mathrm{LC}_{90}$ values with $95 \%$ of fiducial limits were calculated in each bioassay to measure difference between the test samples. The results obtained with different extracts were analysed using student's t-test with statistical significance considered for $\mathrm{P} \leq 0.05$.

\section{RESULTS}

In our study, Coriandrum sativum gave an $\mathrm{LC}_{50}$ of $0.86,1.21,1.54,2.04$ and $2.40 \%$ at 24 hours after the exposure. It gave on $\mathrm{LC}_{90}$ value of $3.71,4.30,5.13$, 5.85 and $6.22 \%$ at 24 hours after the exposure. Piper nigrum gave an $\mathrm{LC}_{50}$ of $0.71,0.94,1.14,1.41$ and $1.82 \%$ at 24 hours after the exposure. It gave on $\mathrm{LC}_{90}$ value of $2.73,3.19,3.41,3.90$ and $4.54 \%$ at 24 hours after the exposure. Cypermethrin gave an $\mathrm{LC}_{50}$ of $0.61,0.69,0.82,0.94$ and $1.06 \%$ at 24 hours after the exposure. It gave on $\mathrm{LC}_{90}$ value of $1.32,1.41,1.60$, 1.77 and $1.80 \%$ at 24 hours after the exposure. These data were used to determine the synergistic factor (Table 1).

The larvicidal activity of Coriandrum sativum and cypermethrin is shown in Table 2. At a larval stage of I, II, III, IV and pupae the $\mathrm{LC}_{50}$ was $1.12,1.41,1.55$, 1.73 and $2.04 \%$ and the $\mathrm{LC}_{90}$ was $3.28,3.61,3.88$, 4.13 and $4.61 \%$ at 24 hours after the treatment. They gave synergistic factors of $0.553,0.489,0.529,0.543$, 0.519 and $0.402,0.390,0.412,0.428,0.390$ for $\mathrm{LC}_{50}$ and $\mathrm{LC}_{90}$ respectively, at 24 hours; which shows antagonistic activity of the combination.

The larvicidal activity of Piper nigrum and cypermethrin is shown in Table 2. At a larval stage of I, II, III, IV and pupae the $\mathrm{LC}_{50}$ was $0.58,0.66,0.91$, 1.04 and 1.66 and the $\mathrm{LC}_{90}$ was $2.40,2.66,2.95,3.27$ 
International Journal of Trend in Scientific Research and Development (IJTSRD) ISSN: 2456-6470

and $4.34 \%$ at 24 hours after the treatment. They gave and $\mathrm{LC}_{90}$ respectively, at 24 hours; which shows synergistic factors of $1.051,1.045,0.901,0.903$, minimum synergistic activity and maximum 0.638 and $0.55,0.530,0.542,0.541,0.414$ for $\mathrm{LC}_{50}$ antagonistic activity of the combination.

Table 1: Larvicidal activity of metanolic seed extracts of Coriandrum sativum, Piper nigrum and Cypermethrin against dengue vector, Aedes aegypti.

\begin{tabular}{|c|c|c|c|c|c|c|}
\hline Product & Stage & $\begin{array}{l}\text { Exposure } \\
\text { period } \\
\text { (Hours) }\end{array}$ & $\begin{array}{l}\text { Regression } \\
\text { co efficient }\end{array}$ & Chi-square & $\begin{array}{c}\mathrm{LC}_{50} \\
\text { (Confidence } \\
\text { limits \%) }\end{array}$ & $\begin{array}{c}\mathrm{LC}_{90} \\
\text { (Confidence } \\
\text { limits \%) }\end{array}$ \\
\hline $\begin{array}{l}\text { Coriandrum } \\
\text { sativum }\end{array}$ & $\begin{array}{l}\text { I instar } \\
\text { II instar } \\
\text { III instar } \\
\text { IV instar }\end{array}$ & 24 & $\begin{array}{l}0.45 \\
0.41 \\
0.36\end{array}$ & $\begin{array}{l}0.27 \\
1.26\end{array}$ & $\begin{array}{c}0.86 \\
(0.40-1.14) \\
1.21 \\
(0.84-1.48) \\
1.54 \\
(1.21-1.90) \\
2.04 \\
(1.70-2.68) \\
2.40 \\
(2.00-3.32)\end{array}$ & $\begin{array}{c}3.71 \\
(3.07-5.03) \\
4.30 \\
(3.48-6.12) \\
5.13 \\
(3.99-8.06) \\
5.85 \\
(4.43-9.77) \\
6.22 \\
(4.68-10.56)\end{array}$ \\
\hline Piper nigrum & $\begin{array}{l}\text { II instar } \\
\text { III instar } \\
\text { IV instar } \\
\text { Pupae }\end{array}$ & $\begin{array}{l}24 \\
24 \\
24 \\
24\end{array}$ & $\begin{array}{c}0.63 \\
0.57 \text { a } \\
0.57 \\
\text { searc } \\
0.52 \\
\text { aelor } \\
0.42\end{array}$ & $\begin{array}{c}0.23 \\
0.39 \\
0.48 \\
1.32 \\
0.39 \\
70\end{array}$ & $\begin{array}{c}0.71 \\
(0.37-0.93) \\
0.94 \\
(0.63-1.16) \\
1.14 \\
(0.88-1.35) \\
1.41 \\
(1.20-1.66) \\
1.82 \\
(1.58-2.13) \\
\end{array}$ & $\begin{array}{c}2.73 \\
(2.39-3.28) \\
3.19 \\
(2.75-3.95) \\
3.41 \\
(2.94-4.24) \\
3.90 \\
(3.30-5.02) \\
4.54 \\
(3.74-6.14)\end{array}$ \\
\hline Cypermethrin & $\begin{array}{l}\text { I instar } \\
\text { II instar } \\
\text { III instar } \\
\text { IV instar } \\
\text { Pupae }\end{array}$ & $\begin{array}{l}24 \\
24 \\
24\end{array}$ & $\begin{array}{l}1.64 \\
1.55 \\
1.43\end{array}$ & $\begin{array}{l}6.07 \\
2.37\end{array}$ & $\begin{array}{c}0.61 \\
(0.33-0.80) \\
0.69 \\
(0.51-0.85) \\
0.82 \\
(0.75-0.90) \\
0.94 \\
(0.76-1.22) \\
1.06 \\
(0.97-1.19)\end{array}$ & $\begin{array}{c}1.32 \\
(1.05-2.14) \\
1.41 \\
(1.16-1.99) \\
1.60 \\
(1.44-1.84) \\
1.77 \\
(1.40-2.84) \\
1.80 \\
(1.72-2.34)\end{array}$ \\
\hline
\end{tabular}

Chi-square value $\mathrm{P}<0.05$, Significant level. 
International Journal of Trend in Scientific Research and Development (IJTSRD) ISSN: 2456-6470

Table 2: Combined action of binary mixtures of Cypermethrin and metanolic seed extracts of Coriandrum sativum, Piper nigrum against dengue vector, Aedes aegypti.

\begin{tabular}{|c|c|c|c|c|c|c|c|c|c|c|}
\hline Product & Stage & $\begin{array}{l}\text { Exposu } \\
\text { re } \\
\text { period } \\
\text { (Hours) }\end{array}$ & $\begin{array}{c}\text { Regressio } \\
\text { n co } \\
\text { efficient }\end{array}$ & $\begin{array}{l}\text { Chi- } \\
\text { squar } \\
\text { e }\end{array}$ & $\begin{array}{c}\mathrm{LC}_{50} \\
\text { (Confiden } \\
\text { ce limits } \\
\% \text { ) }\end{array}$ & SF & $\begin{array}{l}\text { Type } \\
\text { of } \\
\text { action }\end{array}$ & $\begin{array}{c}\mathrm{LC}_{90} \\
\text { (Confiden } \\
\text { ce limits } \\
\% \text { ) }\end{array}$ & SF & $\begin{array}{l}\text { Type } \\
\text { of } \\
\text { action }\end{array}$ \\
\hline $\begin{array}{c}\text { Cypermeth } \\
\text { rin }+ \\
\text { Coriandru } \\
m \text { sativum }\end{array}$ & $\begin{array}{l}\text { I } \\
\text { instar } \\
\text { II instar } \\
\text { III } \\
\text { instar } \\
\text { IV } \\
\text { instar } \\
\text { Pupae }\end{array}$ & $\begin{array}{l}24 \\
24 \\
24\end{array}$ & $\begin{array}{l}0.59 \\
0.58 \\
0.55\end{array}$ & $\begin{array}{l}0.67 \\
1.90 \\
0.89 \\
0.74\end{array}$ & $\begin{array}{c}1.12 \\
(0.87- \\
1.32) \\
1.41 \\
(1.20- \\
1.61) \\
1.55 \\
(1.34- \\
1.77) \\
1.73 \\
(1.52- \\
1.98) \\
2.04 \\
(1.80- \\
2.40)\end{array}$ & $\begin{array}{c}0.55 \\
3 \\
0.48 \\
9 \\
0.52 \\
9 \\
0.54 \\
3 \\
0.51 \\
9 \\
9\end{array}$ & $\begin{array}{c}\text { Antag } \\
\text { onisti } \\
\text { c } \\
\text { Antag } \\
\text { onisti } \\
\text { c } \\
\text { Antag } \\
\text { onisti } \\
\text { c } \\
\text { Antag } \\
\text { onisti } \\
\text { c } \\
\text { Antag } \\
\text { onisti } \\
\text { c }\end{array}$ & $\begin{array}{c}3.28 \\
(2.84- \\
4.02) \\
3.61 \\
(3.11- \\
4.46) \\
3.88 \\
(3.31- \\
4.92) \\
4.13 \\
(3.49- \\
5.29) \\
4.61 \\
(3.83- \\
6.14)\end{array}$ & $\begin{array}{c}0.40 \\
2 \\
0.39 \\
0 \\
\\
0.41 \\
2 \\
\\
0.42 \\
8 \\
\\
0.39 \\
0\end{array}$ & $\begin{array}{c}\text { Antag } \\
\text { onisti } \\
\text { c } \\
\text { Antag } \\
\text { onisti } \\
\text { c } \\
\text { Antag } \\
\text { onisti } \\
\text { c } \\
\text { Antag } \\
\text { onisti } \\
\text { c } \\
\text { Antag } \\
\text { onisti } \\
\text { c }\end{array}$ \\
\hline $\begin{array}{c}\text { Cypermeth } \\
\text { rin }+ \\
\text { Piper } \\
\text { nigrum }\end{array}$ & $\begin{array}{l}\text { I } \\
\text { instar } \\
\text { II instar } \\
\text { III } \\
\text { instar } \\
\text { IV } \\
\text { instar } \\
\text { Pupae }\end{array}$ & $\begin{array}{r}24 \\
24 \\
8\end{array}$ & $\begin{array}{l}0.70 \\
0.64 \\
0.63 \\
0.57 \\
0.48\end{array}$ & $\begin{array}{l}0.01 \\
0.81\end{array}$ & $\begin{array}{c}0.58 \\
(0.24- \\
0.80) \\
0.66 \\
(0.32- \\
1.89) \\
0.91 \\
(0.62- \\
1.11) \\
1.04 \\
(0.76- \\
1.25) \\
1.66 \\
(1.42- \\
1.02)\end{array}$ & $\begin{array}{c}1.05 \\
1 \\
1.04 \\
1.04 \\
5 \\
0.90 \\
1 \\
0.90 \\
3 \\
0.63\end{array}$ & $\begin{array}{c}\text { Syner } \\
\text { gistic } \\
\text { Syner } \\
\text { gistic } \\
\text { Antag } \\
\text { onisti } \\
\text { c } \\
\text { Antag } \\
\text { onisti } \\
\text { c } \\
\text { Antag } \\
\text { onisti } \\
\mathrm{c}\end{array}$ & $\begin{array}{c}2.40 \\
(2.13- \\
2.82) \\
2.66 \\
(2.34- \\
3.20) \\
2.95 \\
(2.59- \\
3.57) \\
3.27 \\
(2.83- \\
4.05) \\
4.34 \\
(3.60- \\
5.81)\end{array}$ & $\begin{array}{c}0.55 \\
0.53 \\
0 \\
\\
0.54 \\
2 \\
\\
0.54 \\
1 \\
\\
0.41 \\
4\end{array}$ & $\begin{array}{c}\text { Antag } \\
\text { onisti } \\
\text { c } \\
\text { Antag } \\
\text { onisti } \\
\text { c } \\
\text { Antag } \\
\text { onisti } \\
\text { c } \\
\text { Antag } \\
\text { onisti } \\
\text { c } \\
\text { Antag } \\
\text { onisti } \\
\text { c }\end{array}$ \\
\hline
\end{tabular}

SF, Synergistic Factor, $\mathrm{P}<0.05$, Significant level.

\section{DISCUSSION}

The strategy of combining different vector control agent has proven to be advantageous in various pest management programs (Caraballo, 2000; Seyoum et al., 2002). Synergistic formulation may be more bioactive than individual pesticides against different pests. A lot of more work has been done on the synergistic activity of synthetic-synthetic pesticides than plant-plant and plant-synthetic pesticide combinations against various insect pests. 
The individual bioefficacy of petroleum ether seed extract of Coriandrum sativum was study and noted their $\mathrm{LC}_{50}$ value of $20.57 \mathrm{ppm}$ and $\mathrm{LC}_{90}$ value of 47.35 ppm had significant toxic effects against the IV instar larvae of Aedes aegypti (Nagella et al., 2012). In this present study showed $\mathrm{LC}_{50}$ and $\mathrm{LC}_{90}$ values of 2.04 and $5.85 \%$.

Sarita Kumar et al. (2011) investigated the laboratory study of bio control potential of hexane extracts of three species of Peppercorns; Long Pepper, Piper longum L., Black Pepper, Piper nigrum and White Pepper, Piper nigrum against larval forms of Aedes aegypti (Diptera: Culicidae), the vector of dengue haemorrhagic fever. The $\mathrm{LC}_{50}$ and $\mathrm{LC}_{90}$ values obtained with hexane extracts of Piper nigrum against the fourth instar larvae were 0.024 and $0.081 \mathrm{ppm}$. In this present study showed $\mathrm{LC}_{50}$ and $\mathrm{LC}_{90}$ values of 1.41 and 3.90 .

Waseem akram et al. (2010) studied the citrus seed extracts from 10 varieties against 4th instar larvae of dengue fever mosquito, Aedes albopictus (Skuse). The results indicate that the extracts from rough lemon and lemon were more effective as larvicides with lowest $\mathrm{LC}_{50}$ (119.993 and $137.258 \mathrm{ppm}$ respectively, after $24 \mathrm{~h}$ of exposure and 108.85 and $119.853 \mathrm{ppm}$ respectively, after $48 \mathrm{~h}$ of exposure) and $\mathrm{LT}_{50}$ values ( 2.51 and $4.91 \mathrm{~h}$, respectively). In the present study, the results indicate that the methanolic extracts from Coriandrum sativum and Piper nigrum seed were more effective as larvicides with lowest $\mathrm{LC}_{50}(0.86$ and $0.71 \%$ respectively, after $24 \mathrm{~h}$ of exposure).

The benzene, hexane, ethyl acetate, methanol and chloroform leaf extract of $A$. paniculata was found to be more effective against $C x$. quinquefasciatus than Ae. aegypti. The $\mathrm{LC}_{50}$ values were $112.19,137.48$, $118.67,102.05,91.20 \mathrm{ppm}$ and 119.58, 146.34, 124.24, 110.12, $99.54 \mathrm{ppm}$ was reported (Govindarajan, 2011). In the present study, methanolic seed extracts of Coriandrum sativum and Piper nigrum was found to be more effective against Ae. aegypti. The $\mathrm{LC}_{50}$ values were $0.86,1.21,1.54$, $2.04,2.40 \%$ and $0.71,0.94,1.14,1.44,1.82 \%$ respectively.

Sulaiman et al. (2002) evaluated Cynoff 25ULV® (cypermethrin $25 \mathrm{~g} / \mathrm{l}$ ) and Solfac UL015® (cyfluthrin $1.5 \% \mathrm{w} / \mathrm{v}$ ) against the sentinel sugar-fed adults and 4th-instar larvae of Aedes aegypti in a housing estate endemic of dengue in Malaysia. The impact of both pyrethroids on field populations of Aedes albopictus and Aedes aegypti larvae was monitored weekly using bottle containers. Both Cynoff 25ULV® and Solfac UL015® showed adulticidal effects and larvicidal effects. This field trial using Cynoff 25ULV ${ }^{\circledR}$ against dengue vectors showed its potential for use in dengue vector control programs. In the present study, the cypermethrin $(10 \%$ EC) showed larvicidal and pupicidal effects.

The combined effect of cypermethrin and Coriandrum sativum possessed antagonistic activity in all observed larval stages (I, II, III, IV and pupae). The synergistic value of $\mathrm{LC}_{50}$ and $\mathrm{LC}_{90}$ was $0.553,0.489,0.529$, $0.543,0.519$ and $0.402,0.390,0.412,0.428,0.390$ for $\mathrm{LC}_{50}$ and $\mathrm{LC}_{90}$ respectively, at 24 hours. The combined effect of cypermethrin and Piper nigrum possessed synergistic activity in larval stages (I, II) at $\mathrm{LC}_{50}$ value and acted antagonistic activity at $\mathrm{LC}_{90}$ value after the treatment of 24 hours and antagonistic activity in observed larval stages (III, IV and pupae). The synergistic value of $\mathrm{LC}_{50}$ and $\mathrm{LC}_{90}$ was 1.051 , $1.045,0.901,0.903,0.638$ and $0.55,0.530,0.542$, $0.541,0.414$ respectively, at 24 hours. Similar observations were noted by (George and Vincent, 2005). It was also seen that synergistic activity was directly proportional to exposure period. This finding is supported by the observations of (George and Vincent, 2005) and (Mohan et al., 2006; 2007).

The seaweeds Caulerpa scalpelliformis and Dictyota dichotoma and mangrove Rhizophora apiculata were extracted in acetone, combined with synthetic insecticides (DDT, $\mathrm{BHC}, \mathrm{HCH}$ and malathion) and evaluated for activity against fourth instar larvae of Aedes aegypti. The extract showed synergism with the insecticide. The highest synergistic activity with all three insecticides especially HCH (Thangam and Kathinesan, 1991). Kalayanasundaram and Das (1985) was tested the larvicidal efficacy of some plant extracts in combination with phenthoate and fenthion against Anopheles stephensi and synergism was observed. Thangam and Kathinesan (1991) reported synersistic activity may be due to plant extract inhibiting some factors, such as detoxitying enzymes, in mosquito larvae, which can act against synthetic pesticides as observed in the larvae of Aedes aegypti. Cobel et al. (2003) observed synergistic activity between permethrin and propoxual giving a $\mathrm{LC}_{50}$ of $0.26 \mathrm{mg} /$ litre and a synergistic factor of 1.54 against Culex quinquefasciatus larvae. The synergism between DEET (N, Ndiethyltoluamide) and propoxur against Aedes aegypti 
was reported by Pennetier et al. (2005). Mohan et al. (2010) investigated the joint action of Solanum xanthocarpum and the synthetic pesticides, fenthion and temphos were evaluated against the larvae of the filarial vector, Culex quinquefasciatus.

\section{CONCLUSION}

In conclusion, the findings of the present study indicate that the combined action of methanolic extracts of Coriandrum sativum, Piper nigrum seeds and synthetic insecticide cypermethrin could be used as a potential larvicidal agent. Combinations of synthetic pesticides are generally more effective and more economical which higher bioefficacy against target organisms but may be more environmentally.

\section{REFERENCES}

1) Abbott, WS 1925. A method of computing the effectiveness of insecticides. J. Econ. Entomol., 18: 265-267.

2) Bernard, CB and Philogene (1993) Insecticide synergists: role, importance and perspectives. $J$. Toxicol. Environ. Health., 38: 199-223.

3) Burdock, GA and Carabin, IG (2009) Safety assessment of coriander (Coriandrumsativum L.) essential oil as a food ingredient. Food Chem. Toxicol., 47: 22-34.

4) Caraballo, AJ (2000) Mosquito repellent action of Neem. J. Am. Mosq. Control Assoc., 16: 45-6.

5) Corbel, V, Chandre, F, Darrient, F, Lardeux, F and Hougard, JM (2003) Synergism between permethrin and propoxur against Culex quinquefasciatus mosquito larvae. Med. Vet. Entomol., 17: 158-64.

6) Duncan, J (1972) Post-treatment effects of sublethal doses of dieldrin on the mosquito Aedes aegypti. Ann. App. Biol., 52: 16.

7) FAO (1992) Pesticide residue in food, Rome.

8) Finney, DJ (1971) Probit Analysis. Cambridge University Press, London. pp. 68-72.

9) George, $\mathbf{S}$ and Vincent, $\mathbf{S}$ (2005) Comparative efficacy of Annona squamosa Linn. And Pongamia globra Vent. to Azadirachta indica A. Juss against mosquitoes. J.Vector Borne Dis., 42:159-63.
10) Govindarajan, $M \quad$ (2011) Evaluation of Antrographis paniculata Burm. extracts against Culex quinquefasciatus and Aedes aegypti. Asian Pac. J. Trop. Med., 4(3): 176- 181.

11) Helson, BV and Surgeoner, GA (1986) Efficacy of cypermethrin for the control of mosquito larvae and pupae, and impact on non-target organisms, including fish. J. Am. Mosq. Control Assoc., 2(3): 269-75.

12) Kalyanasundaram, $M$ and Das (1985) Larvicidal synergistic activity of plant extract for mosquito control. Indian J. Med. Res., 82: 19-23.

13) Kumar, S, Warikoo, $R$ and Wahab, $N$ (2011) Relative larvicidal efficacy of three species of peppercorns against dengue vector mosquito, Aedes aegypti L.J. Entomol. Res. Soc., 13(2): 27-36.

14) Mohan, L, Sharma, $P$ and Srivastava, $C N$ (2006) Evaluation of Solanum xanthocarpum extracts as a synergist for cypermethrin against the filarial vector, Culex quinquefasciatus (Say). Entomol. Res., 36: 220-5.

15) Mohan, L, Sharma, $\mathbf{P}$ and Srivastava, $\mathbf{C N}$ (2007) Comparative efficacy of Solanum xanthocarpum extracts alone and in combination with a synthetic pyrethroid, cypermethrin, against malaria vector, Anopheles stephensi. Southeast Asian J.Trop. Med. Public Health. 38:256-60.

16) Mohan, L, Sharma, $P$ and Srivastava, $C N$ (2010) Combination lavicidal action of Solanum xanthocarpumextract and certain synthetic insecticides against filarial vector, Culex quinquefasciatus (SAY). Southeast Asian J. Trop. Med. Public Health., 41(2).

17) Nagella, P, Kim, MY, Ahmad, A, Thiruvengadam, $M$ and Chung, IM (2012) Chemical constituents, larvicidal effects and antioxidant activity of petroleum ether extract from seeds of CoriandrumsativumL.J. Med. Plants Res. 6(15): 2948-2954.

18) Nour, AH, Elhussein, SA, Osman, NA and Yusoff, MM (2009) A study of the essential oils of four Sudanese accessions of basil (Osimumbasilicum L.) against Anopheles mosquito larvae. Am. J. Applied Sci., 6: 13591363. 
19) Numba, $T$ (1993) The encyclopedia of wakanyaku (Traditional Sino-Japanese Medicine) with color pictures, II. Osaka: Holikusha.

20) Pennetier, C, Corbel, $\mathbf{V}$ and Hougard, JM (2005) Combination of a nonpyrethroidinsecticide and repellent: a new approach for controlling knockdown-resistant mosquitoes. Am. J. Trop. Med. Hyg., 72: 739-44.

21) Periera, J and Wohlgemuth, $R$ (1982) Neem (Azadirachta indica A. Juss) of West African origin as a protectant of stored maize. Z. Ang. Ent., 24: 208-214.

22) Rand, GM and Petrocelli, SR (1985) In: 'Fundamentals of aquatic toxicology, methods and application' (Eds.) Hemisphere publishing corporation, Weshington, USA, pp. 28.

23) Ravera, $O$ (1986) Cadmium in freshwater ecosystem. In: "Cadmium in the Environment". Mislin, $\mathrm{H}$ and Ravera, $\mathrm{O}$ (Eds). Birkhauser Verlag, Basel Switzerland. 50: 75-87.

24) Rueda, LM (2008) Global diversity of mosquitoes (Insecta: Diptera: Culicidae) in freshwater. Dev. Hydrobiol., 595: 477-487.

25) Seyoum, A, Palsson, $K$ and Kung'a, $S$ (2002) Traditional use of mosquito repellent plants in western Kenya and their evaluation in semi-field experimental huts against Anopheles gambiae: ethnobotanical studies and application by thermal expulsion and direct burning. Trans. R. Soc. Trop. Med. Hyg., 96: 225-31.
26) $\mathrm{Su}, \mathrm{HCF}$ and Horvat, $\mathrm{R}$ (1981) Isolation, identification and insecticidal properties of Piper nigrum amides. J. Agric. Food chem., 29:155-118.

27) Sulaiman, S, Pawanchee, ZA, Othman, HF, Shaari, N, Yahaya, S, Wahab, A and Ismail, S (2002) Field evaluation of cypermethrin and cyflthrin against dengue vectors in a housing estate in Malaysia. J. Vec. Eco., pp. 230-234.

28) Thangam, TS and Kathiresan, K (1991) Mosquito larvicidalativity of marine plant extracts with synthetic insecticides. Botanica. Marina., 34(6): 537-539.

29) Vogel (1978) Text book of practical organic chemistry. The English language Book Society and Longaman. London, pp. 1369.

30) Waseem Akram, Hafiz Azhar Ali Kahan, Faisal Hafeez, Hazrat Bilal, Yeon Kook Kim and Jong-Jin Lee (2010) Potential of citrus seed extracts against dengue fever mosquito, Aedes albopictus (Skuse) (Culicidae: Diptera). Pak. J. Bot., 42(4): 3343-3348.

31) WHO (1996) Report of the World Health Organisation informal consultation on the evaluation and testing of Insecticides, 96(1): 96.

32) WHO, 2009. World Health Organization. Dengue and dengue haemorrhagic fever. Fact sheet No. 